\title{
IMPROVEMENT OF SLEEP QUALITY THROUGH PROGRESSIVE RELAXATION IN ELDERLY IN THE SEMPAJA PUSKESMAS AREA
}

Bachtiar Safrudin ${ }^{1}$, Milkhatun ${ }^{2}$

\author{
${ }^{1}$ Dosen Prodi Ilmu Keperawatan Fakultas Ilmu Keperawatan dan \\ Farmasi \\ Universitas Muhammadiyah Kalimantan Timur \\ ${ }^{2}$ Dosen Prodi Ilmu Keperawatan Fakultas Ilmu Keperawatan dan \\ Farmasi \\ Universitas Muhammadiyah Kalimantan Timur \\ *E-mail : mbs134@umkt.ac.id
}

\begin{abstract}
Decreasing physical, psychological and social functions will have an impact on the overall sleep phase of the elderly. An imperfect sleep cycle can cause the elderly not to sleep soundly, often wake up and the total amount of sleep per day will decrease. Nurses can solve these problems with several nursing interventions through progressive relaxation and healthy sleep. The aim of the study was to see the effect of progressive relaxation and healthy sleep on decreasing sleep disturbances in the elderly group. This research uses a quasi experiment design with a pre-post test without control approach. Measurement of sleep quality of the elderly using the Pittsburgh Sleep Quality Index (PSQI) instrument. This analysis uses univariate and bivariate analysis. Bivariate analysis using paired t-test. Analysis of bivariate Wilcoxon correlation data, obtained score correlation coefficient questionnaire about knowledge between (pretest) and after (posttest) given treatment in the form of progressive relaxation of 0,000 with sig numbers or $p$-value $=0,000>$ 0.05 or significant.
\end{abstract}

Keywords: Decreased Sleep disorders, Progressive Relaxation, Healthy Sleep and the elderly Abstract 


\section{INTRODUCTION}

Lanisa changes that occur one of which is the problem of sleep. Decreased sleep quality for the elderly is depression, difficulty concentrating, heart disease, and accidents (Kanender et al, 2015). The impact caused by sleep disturbances for the elderly is the risk of accidents is very high (inside or outside the home), heart problems, difficulty concentrating, and depression. Morin (2012) states the cause of sleep disorders can also be caused by emotional, cognitive, fatigue and unhealthy habits. So one way to overcome these causes is the relaxation method.

According to the research of Ramdhani and Putra (2014), relaxation is one of the techniques of self-management based on the workings of this sympathetic and parasympathetic nervous system. From preliminary study data at the Semapaja Community Health Center, around $20 \%-50 \%$ of the elderly report insomnia and around 17\% experience serious sleep disorders. Relaxation interventions are considered suitable for dealing with problems in the elderly related to sleep.

\section{MATERIAL AND METHOD}

This study used a quasi-experimental design with a pre-post test without control approach. Researchers will intervene in one group without comparison. Treatment interventions were assessed by comparing pre-test and post-test scores (Notoadmodjo, 2012). The sample in this study is a group of elderly who are in the community in the working area of the Sempaja Puskesmas who are aged 60 years and over, which are calculated using a hypothesis test of 2 means that the total sample size is 56 elderly people. The instrument used in this study was a questionnaire that included risk factor variables as characteristics such as the type of disease, coffee consumption habits, environment, duration of illness) (Polit, 2012).

Measurement of sleep quality in the elderly using the Pittsburgh Sleep Quality Index (PSQI) instrument has 18 questions divided into 7 dimensions: sleep latency, sleep duration, sleep quality, efficiency of sleep habits, sleep disturbances, use of sleeping pills and impaired body functions during the day. 36 Questions 1 and 3 for dimensions of sleep efficiency, questions 2 and 5a for dimensions of sleep latency, questions 4 for dimensions of sleep duration, questions $5 b-5 j$ for sleep disorders, questions 6 for dimensions of sleeping drug use, questions 7 and 8 for dimensions of dysfunction sleep during the day, question 9 for the dimension of subjective quality and question 10 to examine if the respondent has a bedmate. Each dimension has a value ranging from 0 (no problem) to 3 (severe problem). The value of each component is then summed to a global score between $0-21$. A global score of $>5$ is considered to have a significant sleep disorder.36 In this study researchers have requested from Indrawati (2013). Total score: number of component scores 1-7 where, $\leq 5=$ good sleep quality $>5=$ poor sleep quality.

The implementation of progressive relaxation technique interventions will be provided through a group process strategy (peer group), which is a form of community nursing intervention 
carried out by involving the participation of elderly groups with the same problem. The intervention implementation of the elderly is divided into 3 groups, with each group member consisting of group 1 of 20 elderly, group 2 of 16 elderly, and group 3 of 20 elderly. Intervention of progressive relaxation techniques is given in the period of each group which is 6 weeks. While the implementation of sleep hygine only looks at comparing instrument scores before and after the intervention.

Sleep Hygiene can be measured using the Sleep Hygiene Index (SHI) Questionnaire (9). This questionnaire is used as a measurement of good or bad behavior or sleep habits and a person's sleep environment. SHI consists of 13 items with answer choices in the range of 1-5 per item. The results of the interpretation of the SHI are divided into 3, namely scores 13-27 (good), 28-40 (moderate), 41-75 (bad). Patchouli, and Lucia (20015). This analysis uses univariate and bivariate analysis. Bivariate analysis using paired t-test with alternative tests using Wilcoxon. 


\section{RESULT AND DISCUSSION}

Frequency Distribution of Characteristics of Elderly Respondents in the Sempaja Community Health Center in 2018

\begin{tabular}{cccc}
\hline & Categori & Frekuency & Presentase (\%) \\
\hline \multirow{3}{*}{ Age } & early elderly & 42 & 75 \\
\cline { 2 - 4 } & late elderly & 14 & 25 \\
\cline { 2 - 4 } Education & Total & 56 & 100.0 \\
\cline { 2 - 4 } & Low & 34 & 60.7 \\
\cline { 2 - 4 } & High & 22 & 39.3 \\
\hline \multirow{2}{*}{ Gender } & Total & 56 & 100 \\
\cline { 2 - 4 } & Male & 34 & 60.7 \\
\cline { 2 - 4 } & Female & 22 & 39.3 \\
\hline
\end{tabular}

Source: Data primer 2018

The education figure of the study sample was 56 people with the majority of respondents having low education as many as 34 people (60.7\%), and 22 people (39.3\%) had high education. The sex of the sample of the study was 34 people, the majority of respondents $(60.7 \%)$ were men and women were 22 people $(39.3 \%)$.

Distribution of Respondents Based on the value of Knowledge and Sleep Disorders Pre Test and Post Test in the Elderly in the Sempaja Community Health Center 2018.

\begin{tabular}{ccccc}
\hline Variabel & Mean & SD & Min & Max \\
$\begin{array}{c}\text { Knowledge } \\
\text { sleep disturbance Pre-test }\end{array}$ & 38.59 & 16.88 & 14 & 70 \\
\hline $\begin{array}{c}\text { Knowledge } \\
\text { sleep disturbance Post-test }\end{array}$ & 34.04 & 15.31 & 14 & 68 \\
\hline Sleep disturbancePre-test & 5.142 & 1.299 & 3 & 7 \\
\hline Sleep disturbance Post-test & 4.964 & 1.320 & 2 & 7 \\
\hline
\end{tabular}

Source: Data primer 2018

The relationship between the fulfillment of average knowledge before progressive relaxation is 38.59 with a standard deviation of 16.88 where the lowest knowledge is 14 and the highest value is 70 . While after progressive relaxation therapy is obtained the average knowledge value is 34.04 with a standard deviation of 15.31 where the lowest knowledge value is 14 and the highest knowledge value is 68 . The data are normally distributed then the normality test is done descriptively and analytically. Analytically done using the Kolmogorov Smirnov test. It is known that the significance value for pre test data is 0,000 , 

and post test data is 0,000 . Because the significance for the entire research group is smaller than $\alpha(0.05)$, it can be concluded that the research data is not normally distributed.

The average quality of sleep before progressive relaxation is 5,142 with a standard deviation of 1.299 where the lowest sleep disturbance is 3 and the highest value is 7 . While after progressive relaxation therapy is obtained the average value of sleep quality is 4.964 with a standard deviation of 1.320 where the lowest knowledge value is 2 and the highest value of sleep quality is 7 . Test normality descriptively and analytically. Analytically done using the Kolmogorov-Smirnov test. It is known that the significance value for pre test data is 0,000 , and post test data is 0,000 . Because the significance for the entire research group is smaller than $\alpha(0.05)$, it can be concluded that the research data is normally distributed.

The influence between progressive relaxation variables and healthy sleep knowledge which is done by using the Wilcoxon correlation test, correlation coefficient scores obtained questionnaire about knowledge between before (pre test) and after (post test) given treatment in the form of progressive relaxation of 0,000 with sig or $p$ - value $=0.000>0.05$ or significant. the influence between progressive relaxation variables and healthy sleep knowledge which is performed calculations using the Wilcoxon correlation test, obtained correlation coefficient score questionnaire about knowledge between before (pre test) and after (post test) given treatment in the form of progressive relaxation of 0,000 with sig or $p$ - value $=0.000>$ 0.05 or significant.

\section{Analysis of the Effect of Progressive Relaxation on Sleep Quality in the Elderly in the Semaja Community Health Center in 2018.}

Based on the results of research conducted in the working area of the Sempaja Community Health Center using Wilcoxon test because the data distribution is not normal. When given progressive relaxation treatment with the desired expectations is better sleep quality.

Based on statistical test results obtained Wilcoxon test results, namely $\mathrm{p}$ value $=0.000$ $(\mathrm{p}<0.05)$. This value is smaller than the significance level of 0.05 . So it can be concluded 
that there is an effect of progressive relaxation therapy on sleep quality in the elderly in the work area of Semapaja Health Center.

According to Pranata (2013) progressive muscle relaxation can increase physical and psychological activity. The movement of relaxation and muscle contraction can stimulate the parasympathetic nervous system, namely the nucleus rafe which is located under the pons and medulla so that there will be a decrease in body metabolism, pulse, blood pressure, breathing frequency, increased serotonin secretion which can cause the body to relax and easily fall asleep. When doing relaxation movements nerve cells will release opiate peptides which is a sense of comfort that is flowed throughout the body (Robinson, 2016). Progressive muscle relaxation will reduce cortisol production in the blood, reduce levels of noreprineprine, stimulate suprachiasmatic nuclei to produce a pleasant sensation and drowsiness (Potter \& Perry, 2005). Through progressive muscle relaxation exercises the elderly are trained to present a relaxation response so as to achieve a calm state because relaxation exercises provide subtle massage to various glands of the body (Woolfolk, Robert L., McNulty Terrence, 2010).

\section{CONCLUSION}

Bivariate data analysis of Wilcoxon Correlation, obtained correlation coefficient score of the questionnaire about knowledge between before (pre test) and after (post test) was given treatment in the form of progressive relaxation of 0,000 with sig or $\mathrm{p}$-value $=$ $0,000>0.05$ or significant.

Further research is expected to explore other complementary therapies that can be done to overcome problems in the elderly. In addition to aspects of sleep due to lanisia problems related to sleep caused by factors that are sufficiently coping, for example activity, diet and environment

Based on the analysis and discussion, the following conclusions are obtained: 1) For researchers, it is hoped that this research can add new discourses and new concepts that can be taught to students and community nurses in implementing special nursing interventions in the elderly with sleep disorders. 2) For the Muhammadiyah University of East Kalimantan, give a little time to do the assigned academic work. 3) For Researchers Furthermore, exploring other complementary therapies that can be done to overcome problems in the elderly. In addition to aspects of sleep due to lanisia problems related to sleep caused by factors that are sufficiently coping, for example activity, diet and environment 


\section{REFERENCES}

1. Badan Pusat Statistik (BPS). Proyeksi Penduduk Indonesia Indonesia Population Projection 2010-2035. Jakarta: Badan Pusat Statistik. (2013)

2. Badan Pusat Statistik Kota Samarinda. Kota Samarinda dalam Angka 2012. Tersedia online di http://bpskotasamarinda.go.id, diakses tanggal 05 Januari 2017 pukul 20.00 Wita.

3. Profil Kesehatan UPT Puskesmas Sempaja, tidak dipublikasikan. (2015)

4. Ernawati dan Agus, S. Faktor-Faktor Yang Berhubungan Dengan Terjadinya Insomnia Pada Lanjut Usia Di Desa Gayam Kecamatan Sukoharjo Kabupaten Sukoharjo. Tersedia onlien di http://publikasiilmiah.ums.ac.id/bitstream/handle/123456789/3706/ERNAWATI\%20$\% 20 A G U S \% 20$ SUDARYANTO\%20fix\%20BGT.pdf?sequence=1. Diakses pada tanggal 03 Oktober 2016 pukul 20.00 Wita.

5. Ebersole, P., Hess, P., \& Touhy, T. (2005). Gerontological Nursing \& Helathy Aging. (2nd ed). (2005)

6. Miller, C.A. Nursing for wellness in older adults. $6^{\text {th }}$ ed. USA: Lippincott Williams \& Wilkins; (2012)

7. Notoatmodjo, S. Metodologi penelitian kesehatan. Jakarta : Rinneka Cipta.(2012)

8. Polit, D. F., \& Beck, C. T.. Nursing research : appraisal evidence for nursing practice (7th ed.).Philadelphia : Lippincot; (2012).

9. Saedi, M., Ashktorab, Tahereh., Saatchi, Kiarash., Zayeri, Farid., Amir, Sedighe., \& Akbari, Ali. The Effect Of Progressive Muscle Relaxation On Sleep Quality Of Patients Undergoing Hemodialysis. Journal Of Critical Care Nursing. Vol. 5 No.1; (2012).

10. Robinson, V.M. (2016). The Relative Roles of Family and Peer Support in Metabolic Control and Qualityof Life for Adolscents with Type I Diabetes. The University of Edinburgh. Tersedia Online di http://www.Mendeley.com/research diakses pada tanggal 25 Maret 2017 pukul 20.00 Wita.

11. Potter \& Perry. Fundamental Keperawatan Konsep, Proses, dan Praktik, Edisi 4. EGC: Jakarta; (2005)

12. Woolfolk, Robert L., McNulty Terrence F. Relaxation Treatment for Insomnia: A Componen Analysis. Journal of Consulitng and clinical Psychology. Vol 51 No 4, 495-503; (2010). 